Pacific Journal of Mathematics

CORRECTION TO: CHAINS OF INFINITE ORDER AND THEIR
APPLICATION TO LEARNING THEORY 


\title{
ERRATA
}

Correction to

\section{CHAINS OF INFINITE ORDER AND THEIR APPLICATION TO LEARNING THEORY}

\author{
John LAMPERTI AND PATRICK SUPPeS
}

Volume 9 (1959), 739-754

Professor M. Iosifescu has pointed out to us an error in our paper [1]. The difficulty lies in the positivity condition

$$
p_{j_{0}}^{\left(n_{0}\right)}(x) \geqq \delta \geqq 0 \quad \text { for every } x,
$$

which is not strong enough when $n_{0}>1$. Iosifescu has in fact given an example of a second order Markov chain satisfying (2.3) with $n_{0}=0$ for which $\lim _{n \rightarrow \infty} p_{i}^{(n)}(x)$ is not independent of $x$ as asserted by Theorem 2.1 .

The difficulty can be overcome by making the stronger assumption that for some state $j_{0}$, some positive integer $n_{0}$, and some sequence of positive numbers $\delta_{m}$,

$$
p_{j_{0}^{m} m}^{\left(n_{0}\right)}(x) \geqq \delta_{m} \quad \text { for every } x \text { and } m .
$$

Here $p_{x_{m}}^{(n)}(x)$ is the joint probability (defined formally by (2.11) and (2.12)) of executing the sequence $x_{m}$ after $n$ steps, given $x$, and $j_{0}^{*} m$ means a sequence of $m$ repetitions of $j_{0}$. Thus we are asserting that the event, consisting of $m$ consecutive visits to $j_{0}$ starting after a lapse of time $n_{0}$, has positive probability uniformly in $x$ (not in $m$ ). If $n_{0}=1,\left(2.3^{\prime}\right)$ follows from (2.3) with $\delta_{m}=\delta^{m}$, and our error lay in the tacit use of $\left(2.3^{\prime}\right)$, rather than (2.3), in proving Lemma 2.2 in our paper. When $\left(2.3^{\prime}\right)$ is assumed the argument given is valid. Lemma 2.1 does in fact follow from (2.3) and (2.5) as asserted, and so with the new hypothesis the conclusions of $\S 2$ are justified.

Let us consider the effect of this change on the application to linear learning models. Assumption (ii) (b) of Theorem 4.1, which is used to derive (2.3), is now seen to be inadequate for the conclusions of the theorem. However the special case (4.5), when $m_{0}=0$, yields (2.3) with $n_{0}=1$ and so the results are valid in this situation. Although $\left(2.3^{\prime}\right)$ could be adapted to yield greater generality, we take it that essentially all cases of interest are actually covered by (4.5), and

Received April 10, 1965. 
shall leave the matter so. A similar remark applies to Theorem 4.2.

\title{
REFERENCE
}

1. John Lamperti and Patrick Suppes, 'Chains of infinite order and their application to learning theory,' Pacific J. Math. 9 (1959), 739-754.

Correction to

\section{NON-LINEAR DIFFERENTIAL EQUATIONS ON CONES IN BANACH SPACES}

\author{
Charles V. Coffman \\ Volume 14 (1964), 9-15
}

In [1] the proof of a main lemma, Lemma 3.1, contains an error. The lemma itself is false without stronger hypotheses. The purpose of this note is to state and prove a lemma which can be used in place of Lemma 3.1 in the proofs of Theorem 4.1 and 5.1 in [1].

Let $Y$ be a Banach space, let $P$ be a closed linear manifolds in $Y^{*}$ which is total for $Y^{1}$ Assume that $I$ is some real interval. The differential equation with which [1] is concerned is

$$
d y / d t=f(t, y) \text {, }
$$

where $f$ is a function from $I \times C \rightarrow Y$ which is continuous with respect to the weak $\Gamma$-topology on $Y$; $C$ is a subset of $Y$. The notation and terminology used here will be the same as that employed in [1]; the definition of a weak $\Gamma$-derivative, a weak $\Gamma$-solution of (1), etc., are to be found in [1].

Let $\mathscr{C}$ be the space of weakly $\Gamma$-continuous functions on $I$ with values in $C$, furnished with the topology of uniform convergence (in the weak $\Gamma$-topology) on compact subintervals of $I$. If $C$ is compact in the weak $\Gamma$-topology, then Ascoli's theorem implies that a set of equicontinuous functions in $\mathscr{C}$ is relatively compact in $\mathscr{C}$. However unless the topology on $\mathscr{C}$ satisfies the first axiom of countability one cannot conclude from Ascoli's theorem, as is done in [1], that an equicontinuous sequence of functions in $\mathscr{C}$ has a convergent subsequence. ( $\mathscr{C}$ will satisfy the first axiom of countability, for example,

Received March 3, 1965.

1 In [1] a total manifold is defined but is incorrectly called a determining manifold. The author wishes to thank the referee of this note for pointing out this mistake as well as for correcting an omission in the original proof of the lemma stated here. 


\title{
PACIFIC JOURNAL OF MATHEMATICS
}

\author{
EDITORS
}

\author{
H. SAmelson \\ Stanford University \\ Stanford, California \\ R. M. Blumenthal \\ University of Washington \\ Seattle, Washington 98105
}

\author{
J. DugundjI \\ University of Southern California \\ Los Angeles, California 90007
}

*Richard Arens

University of California

Los Angeles, California 90024

\section{ASSOCIATE EDITORS}
E. F. BECKENBACH
B. H. NeUmanN
F. WOLF
K. YoSIDA

\section{SUPPORTING INSTITUTIONS}

\author{
UNIVERSITY OF BRITISH COLUMBIA \\ CALIFORNIA INSTITUTE OF TECHNOLOGY \\ UNIVERSITY OF CALIFORNIA \\ MONTANA STATE UNIVERSITY \\ UNIVERSITY OF NEVADA \\ NEW MEXICO STATE UNIVERSITY \\ OREGON STATE UNIVERSITY \\ UNIVERSITY OF OREGON \\ OSAKA UNIVERSITY \\ UNIVERSITY OF SOUTHERN CALIFORNIA
}

\author{
STANFORD UNIVERSITY \\ UNIVERSITY OF TOKYO \\ UNIVERSITY OF UTAH \\ WASHINGTON STATE UNIVERSITY \\ UNIVERSITY OF WASHINGTON \\ * * * * \\ AMERICAN MATHEMATICAL SOCIETY \\ CALIFORNIA RESEARCH CORPORATION \\ SPACE TECHNOLOGY LABORATORIES \\ NAVAL ORDNANCE TEST STATION
}

Mathematical papers intended for publication in the Pacific Journal of Mathematics should by typewritten (double spaced). The first paragraph or two must be capable of being used separately as a synopsis of the entire paper. It should not contain references to the bibliography. No separate author's resumé is required. Manuscripts may be sent to any one of the four editors. All other communications to the editors should be addressed to the managing editor, Richard Arens, at the University of California, Los Angeles, California 90024.

50 reprints per author of each article are furnished free of charge; additional copies may be obtained at cost in multiples of 50 .

The Pacific Journal of Mathematics is published quarterly, in March, June, September, and December. Effective with Volume 13 the price per volume (4 numbers) is $\$ 18.00$; single issues, $\$ 5.00$. Special price for current issues to individual faculty members of supporting institutions and to individual members of the American Mathematical Society: $\$ 8.00$ per volume; single issues $\$ 2.50$. Back numbers are available.

Subscriptions, orders for back numbers, and changes of address should be sent to Pacific Journal of Mathematics, 103 Highland Boulevard, Berkeley 8, California.

Printed at Kokusai Bunken Insatsusha (International Academic Printing Co., Ltd.), No. 6, 2-chome, Fujimi-cho, Chiyoda-ku, Tokyo, Japan.

PUBLISHED BY PACIFIC JOURNAL OF MATHEMATICS, A NON-PROFIT CORPORATION

The Supporting Institutions listed above contribute to the cost of publication of this Journal, but they are not owners or publishers and have no responsibility for its content or policies.

* Basil Gordon, Acting Managing Editor until February 1, 1966. 


\section{Pacific Journal of Mathematics}

\section{Vol. 15, No. $4 \quad$ December, 1965}

Robert James Blattner, Group extension representations and the structure space ........... 1101

Glen Eugene Bredon, On the continuous image of a singular chain complex .............. 1115

David Hilding Carlson, On real eigenvalues of complex matrices .................... 1119

Hsin Chu, Fixed points in a transformation group ............................. 1131

Howard Benton Curtis, Jr., The uniformizing function for certain simply connected Riemann

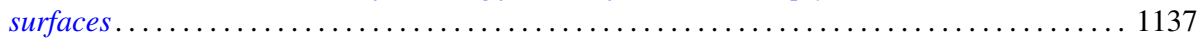

George Wesley Day, Free complete extensions of Boolean algebras................... 1145

Edward George Effros, The Borel space of von Neumann algebras on a separable Hilbert

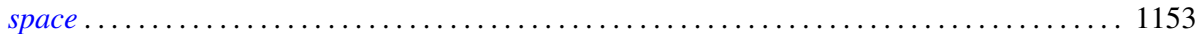

Michel Mendès France, $A$ set of nonnormal numbers ......................... 1165

Jack L. Goldberg, Polynomials orthogonal over a denumerable set ................ 1171

Frederick Paul Greenleaf, Norm decreasing homomorphisms of group algebras . . . . . . . . 1187

Fletcher Gross, The 2-length of a finite solvable group ........................ 1221

Kenneth Myron Hoffman and Arlan Bruce Ramsay, Algebras of bounded sequences ........ 1239

James Patrick Jans, Some aspects of torsion . . . . . . . . . . . . . . . . . . . . . . . 1249

Laura Ketchum Kodama, Boundary measures of analytic differentials and uniform

approximation on a Riemann surface ............................... 1261

Alan G. Konheim and Benjamin Weiss, Functions which operate on characteristic

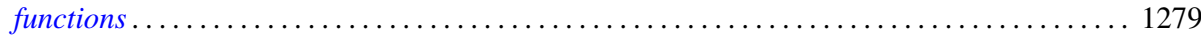

Ronald John Larsen, Almost invariant measures ............................ 1295

You-Feng Lin, Generalized character semigroups: The Schwarz decomposition ............ 1307

Justin Thomas Lloyd, Representations of lattice-ordered groups having a basis . . . . . . . . 1313

Thomas Graham McLaughlin, On relative coimmunity ....................... 1319

Mitsuru Nakai, $\Phi$-bounded harmonic functions and classification of Riemann surfaces ....... 1329

L. G. Novoa, On n-ordered sets and order completeness ..................... 1337

Fredos Papangelou, Some considerations on convergence in abelian lattice-groups . . . . . . . 1347

Frank Albert Raymond, Some remarks on the coefficients used in the theory of homology

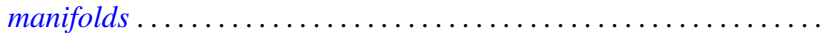

John R. Ringrose, On sub-algebras of a $C^{*}$-algebra .

Jack Max Robertson, Some topological properties of certain spaces of differentiable

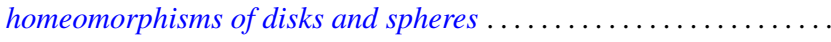

Zalman Rubinstein, Some results in the location of zeros of polynomials

Arthur Argyle Sagle, On simple algebras obtained from homogeneous general Lie triple systems. . . .

Hans Samelson, On small maps of manifolds ............................... 1401

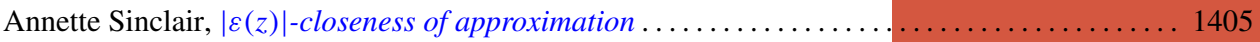

Edsel Ford Stiel, Isometric immersions of manifolds of nonnegative constant sectional curvature

Earl J. Taft, Invariant splitting in Jordan and alternative algebras ................. 1421

L. E. Ward, On a conjecture of R. J. Koch . . . . . . . . . . . . . . . . . . . . . . . . . . . 1429

Neil Marchand Wigley, Development of the mapping function at a corner . . . . . . . . . . 1435

Horace C. Wiser, Embedding a circle of trees in the plane ....................... 1463

Adil Mohamed Yaqub, Ring-logics and residue class rings . . . . . . . . . . . . . . . . 1465

John W. Lamperti and Patrick Colonel Suppes, Correction to: Chains of infinite order and their application to learning theory ........................................ 1471

Charles Vernon Coffman, Correction to: Non-linear differential equations on cones in Banach

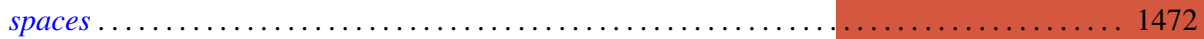

P. H. Doyle, III, Correction to: A sufficient condition that an $\operatorname{arc}$ in $S^{n}$ be cellular. . . . . . . . 1474

P. P. Saworotnow, Correction to: On continuity of multiplication in a complemented algebra 